\title{
GREEN BENEFITS ON EDUCATIONAL BUILDINGS ACCORDING TO THE LEED CERTIFICATION
}

\author{
Ji-Myong KIM (D) 1, Kiyoung SON (D) 2, Seunghyun SON (D) 3,* \\ ${ }^{1}$ Department of Architectural Engineering, Mokpo National University, Mokpo, Republic of Korea \\ ${ }^{2}$ School of Architectural Engineering, University of Ulsan, Ulsan, Republic of Korea \\ ${ }^{3}$ Department of Architectural Engineering, Kyung Hee University, Suwon, Republic of Korea
}

Received 03 February 2019; accepted 06 August 2019

\begin{abstract}
Countries around the world are making efforts to develop and introduce green building certification systems to save energy and reduce greenhouse gas emissions. As a result of these efforts, green certification systems are rapidly spreading. Consistent with this, certification systems are also being developed and research related to various technologies and regulations is ongoing. However, most research focuses on residential and commercial buildings and there is still a lack of scientific research on educational facilities. To fill the gap and support the former studies, this research statistically studies the economic effects of green certification systems on educational facilities. For this purpose, the benefits, i.g., building price and maintenance \& repair costs, were examined for universities in Canada that were admitted to the Canadian Educational Institution. As shown by the results of this study, Leadership in Energy and Environmental Design (LEED)-certified buildings cost $49.9 \%$ more to build and had $25.6 \%$ lower maintenance and repair costs than non-LEED certified buildings.
\end{abstract}

Keywords: LEED, maintenance and repair cost, construction cost, education facilities, T-test.

\section{Introduction}

The green building certification system was developed to improve building efficiency and sustainability. The ultimate goals of such certification systems are to promote preservation of the global environment as well as the comfort of occupants and their health. The system assesses categories such as energy, raw materials, and pollutant emissions over the entire building life cycle, including the design, construction, maintenance, and dismantling of the building. There are several well-known certification systems such as Building Research Establishment's Environmental Assessment Method [BREEAM] (1991) in the UK, Leadership in Energy and Environmental Design [LEED] (1998) in the U.S. These systems not only have the direct effect of encouraging construction of green buildings, but they also have the additional effect of enhancing the public's awareness of environmental preservation and promoting green technology developments and research activities. Owing to these effects, various studies are underway on the premiums of environmentally friendly certification systems such as occupancy rate, rental rate, sale price, and energy efficiency. However, research is being conducted mainly on commercial and office buildings. Hence, there is still a lack of scientific research on educational facilities. For in-depth study of economic effects, this study examined the various economic effects of the Green Building Certification System through previous studies, as well as the past research on the Green Building Certification System related to educational facilities. In addition, LEED and its composition and evaluation items of the Green Building Certification System were discussed. For scientific evidence of economic effects, this study statistically studies the economic impact of green building certification systems on educational facilities to reduce gaps and support previous research. To achieve this goal, the study examined Canadian universities' economic benefits: building prices, maintenance and repair costs. T-test is adopted for statistical analysis, and the population is divided into LEED building and Non-LEED building for comparison group.

*Corresponding author. E-mail: seunghyun@khu.ac.kr 


\section{Literature review}

\subsection{Previous studies}

Green certification systems are emerging megatrends. Why invest our money in green certification? When they select it, they consider, "We are doing good or doing the right thing". Though guiding and trending towards more beneficial and healthful pathways is not enough to expand investment in green certification systems. The green certification system is an investment for the present and next generations for wellbeing, subsequently the environmental and social as well as economic aspects should be considered. Thus, does the green certification system actually have an economic impact? The answer is yes. Green certification systems are one of the strongest elements in the real estate market (Fuerst \& McAllister, 2009b; Eichholtz, Kok, \& Quigley, 2009, 2013). LEED and Energy Star are the most common green certification systems in the United States. LEED is accepted as a requirement in many cities in the United States and has been encouraged to encourage system use (May \& Koski, 2007). Oil and banking companies are key customers of green buildings, and choose green certification as part of their green strategy (Eichholtz, Kok, \& Quigley, 2010). Consequently, green certification systems also represent a great reputation for buildings. Many studies have described various aspects of green certification to justify potential investments. Green buildings offer numerous paybacks than conventional buildings. LEED certified buildings consume less $32 \%$ in electricity and reduced average 385 tons yearly in $\mathrm{Co}_{2}$ emission (Bon \& Hutchinson, 2000). Moreover, the operation costs of green buildings are 4 to 5 times greater than the premium in early stage of construction owing to the benefits, e.g., the less usage of water, energy, the occupant's higher productivity and better health. Kats (2003) reports that the total net benefit (20 years) of green building is $\$ 50$ to $\$ 65$ per $\mathrm{ft}^{2}$ which are 10 times larger than the average investment cost in early stage for design and construction. Additionally, green buildings make a contribution to efficiency of organization and performance of business. Therefore, the green building is a definitely great investment regarding the worth and positive influence to property-owner, occupant, and stakeholder (Gou, Lau, \& Prasad, 2013; Heerwagen, 2000). Furthermore, such research has explained the relationship among the green certifications and benefits such as rental rate, occupancy rate, sale price, energy efficiency and so on. Miller, Spivey, and Florance (2008) investigate eco-labeling systems, i.e., LEED and Energy Star, and their benefits such as rental rate, occupancy rate, and sale price. They compare a non-labeled building to a labeled building for commercial buildings utilizing regression analyses and define the relationship between the occupancy rate and energy efficiency. The results show that the occupancy rate is approximately $2-4 \%$ higher and the energy expenses are approximately 30\% lower in Energy Star labeled buildings compared to non-Energy Star labeled buildings. Wiley, Benefield, and
Johnson (2010) examine office buildings that are labeled and certified by Energy Star and LEED and define the relationships using regression analyses. In particular, their research verifies the profits of green buildings. The rent is $7-17 \%$ higher and occupancy rate is $10-18 \%$ higher. The sale price is also higher by $\$ 30 / \mathrm{ft}^{2}$ for Energy Star labeled buildings and $\$ 130 / \mathrm{ft}^{2}$ for LEED-certified buildings. Eichholtz et al. (2013) explore the benefits of eco-labeled office buildings (Energy Star and LEED) employing regression analyses. They find that the energy efficiency, rent, and building value of green buildings are all higher than those of non-green buildings owing to the green buildings' sustainability and thermal effectiveness. Eichholtz et al. (2010) describe the relationship among sales price, rental rate and green certifications utilizing regression analysis. They identify green office properties that are certified Energy Star or LEED and the control sample is within a quarter mile of the certified properties. The results show that energy efficiency and rental rate have positive relationships with green certification. Fuerst and McAllister (2009a) demonstrate paybacks of eco-labeling systems, specifically LEED and Energy Star, using regression analyses. They find that occupancy rate is approximately $6 \%$ and $5 \%$ higher in LEED certified buildings and Energy Star labeled buildings, respectively. Moreover, the sale prices are approximately $35 \%$ and $31 \%$ greater for LEED certified buildings and Energy Star labeled buildings, respectively. Numerous studies have been conducted to identify the relationships between green certifications and premiums. However, the studies have focused on direct premiums such as rental rate, occupancy rates, sale price, and energy efficiency and studies are primarily concentrated on commercial buildings (Kim, Yang, \& Min, 2012; Lee, 2013). Consequently, there is a need for further study of education buildings to identify various impacts of green certifications. This study statistically examines both building value and maintenance and repair cost.

Ha, Son, J. M. Kim, and T. H. Kim (2017) conducted a comparative study on the construction costs according to the LEED certification of educational buildings. As a result, initial construction costs increased by $3.8 \%$ due to increased initial design costs and the use of relatively expensive eco-friendly materials. However, according to US Green Building (2006), when compared to LEED-certified buildings and non-certified buildings, it is reported that there would be a profit in the long-term against additional construction costs regarding energy use, pollutant emissions, water usage, asthma incidence, and respiratory disease. In addition, Chen, Yang, and $\mathrm{Lu}$ (2015) and Gou and Lau (2014) reported that it can be reduced the maintenance costs because there is various effectiveness such as energy saving and health improvement through indoor air quality improvement although the construction costs are increased by introducing eco-friendly facility system, designing, and modeling. In this respect, many researchers have been conducted the research regarding the qualitative economic effects through the eco-friendly certifica- 
tion system. However, the research is needed to analyze the effects quantitatively. Therefore, this study is to analyze quantitatively the economic effects between certified and non-certified educational buildings by using the building price, maintenance and repair expenses data.

\subsection{Green benefits in school}

The eco-friendly environment of green building significantly impacts on occupants, i.e., teacher, staff and student who are learning and working at schools. The reasons are that the green environments, e.g., thermal comfort, air quality, organization of space, light, have positive effects on the occupants. Consequently, the green school offers better health and comfort, well-light and helps to students' learning and accomplishment whereas reduces the resource and energy. Shendell et al. (2004) reported that students' absences increased as the amount of $\mathrm{CO}_{2}$ in the class increased. Moreover, the United States Environmental Protection Agency [USEPA] stated that indoor air quality, which includes pollutants, temperature, and humidity, has been shown to affect students' health and academic performance (United States Environmental Protection Agency, 2000). Moreover, from an economic point of view, the green school save the approximately $\$ 3$ per $\mathrm{ft}^{2}$ or $2 \%$ less than non-green building. The total fiscal benefits are about $\$ 70$ per $\mathrm{ft}^{2}$ which are twelve times bigger than the investment cost for green building i.e., $\$ 3$ per $\mathrm{ft}^{2}$. The total savings are sum of direct cost from separate green building are sum of savings, e.g., the water and energy, health related cost and so on (Kats, 2006). However, even if the movement for green-friendly educational facilities is growing, there is little information regarding educational buildings with green certifications. To understand the costs and benefits of green certification for educational buildings, this study analyzed premiums based on certified green buildings that are used as educational facilities.

\subsection{LEED}

USGBC has been implementing environmentally friendly building evaluations through LEED (Leadership in Energy \& Environmental Design) since 1998. It has been revised based on improvements in technology. In 2009, LEED version 3 was integrated into five evaluation systems after it was revised from LEED version 4 in 2013 into 10 independent evaluation systems. The types of evaluation systems are: LEED for BD+C, LEED for ID+C, LEED for O+M, LEED for ND, Neighborhood Development, and LEED for HOMES. The newly added subcategories are healthcare, data centers, hospitality, warehouses, distribution centers, retail, schools, plans, and built projects. Currently, the LEED version $4 \mathrm{BD}+\mathrm{C}$ (school) grading system is classified as $40-49$ points to Certified, $50-59$ points to Silver, $60-79$ to Gold, $80-110$ to Platinum. Table 1 shows the transition of rating categories for LEED for a $\mathrm{BD}+\mathrm{C}$ (school) system. It was changed from version 2 to version 3 , and changed from 79 points to 110 points. The
Table 1. Transition of the LEED evaluation categories

\begin{tabular}{|l|c|c|c|}
\hline \multicolumn{1}{|c|}{ Evaluation category } & Version 2 & Version 3 & Version 4 \\
\hline Energy and atmosphere & $22 \%$ & $29 \%$ & $27 \%$ \\
\hline Indoor environmental quality & $24 \%$ & $17 \%$ & $15 \%$ \\
\hline Location and transportation & - & - & $13 \%$ \\
\hline Materials and resources & $17 \%$ & $12 \%$ & $12 \%$ \\
\hline Sustainable sites & $20 \%$ & $22 \%$ & $11 \%$ \\
\hline Water efficiency & $9 \%$ & $10 \%$ & $11 \%$ \\
\hline Innovation & $8 \%$ & $6 \%$ & $6 \%$ \\
\hline Regional priority & - & $4 \%$ & $4 \%$ \\
\hline Integrative process & - & - & $1 \%$ \\
\hline Total & $100 \%$ & $100 \%$ & $100 \%$ \\
\hline
\end{tabular}

regional environment characteristics are considered by adding new regional items, which can receive additional points by taking advantage of the local environment characteristics. The sustainable site section has been updated with alternative transportation-related items to reduce pollutant emissions from personal transportation such as public transportation access and bicycle storage. The energy and atmosphere category showed the largest increase, while the indoor environmental quality category showed the greatest decrease.

\section{Method}

The purpose of this study is to compare and analyze the premiums of LEED certified buildings and non-LEED certified buildings. This study conducted statistical analyses based on data from education facilities as a qualitative study. The premiums for the certification system were limited to the building price maintenance and repair costs. The analysis conducted in this study is as follows. (1) 62 universities belonging to the Canadian Universities Reciprocal Insurance Exchange (CURIE) were selected as the population, and LEED certified buildings and nonLEED certified buildings were classified as the sample. (2) The building price and maintenance and repair cost data were collected for LEED certified and non-LEED certified buildings. (3) Normality tests were performed for statistical analysis, and the data were analyzed using a T-test. (4) The premiums were calculated based on LEED certification using statistical analysis.

\subsection{Data collection}

This study accepted the records from Canadian Universities Reciprocal Insurance Exchange (CURIE) to examine the financial premiums of building value and maintenance and repair costs for educational properties. CURIE is an insurance provider for universities in Canada since 1988. This organization covers physical loss on property, automobiles, and equipment, and provides general liability insurance. This data consists of two main part, i.e., list of properties and loss record. The list of properties consists 
Table 2. Descriptive statistics

\begin{tabular}{|l|l|c|c|c|c|c|}
\hline LEED rating & \multicolumn{1}{|c|}{ Category } & $\mathrm{N}$ & Minimum & Maximum & Mean & Std. Deviation \\
\hline \multirow{4}{*}{$\begin{array}{l}\text { Non-LEED } \\
\text { building }\end{array}$} & Building value $(\$)$ & 3.396 & $1,490.0$ & $601,000,000.0$ & $14,068,000.0$ & $28,896,800.0$ \\
\cline { 2 - 7 } & Building area $\left(\mathrm{ft}^{2}\right)$ & 3.396 & $1,017.0$ & $1,305,080.0$ & $45,975.7$ & $78,851.5$ \\
\cline { 2 - 7 } & Maintenance repair cost $(\$)$ & 3.396 & - & $9,409,640.0$ & $745,639.0$ & $1,780,143.0$ \\
\cline { 2 - 7 } & Building value ratio $\left(\$ / \mathrm{ft}^{2}\right)$ & 3.396 & 0.1 & $16,203.9$ & 250.5 & 433.5 \\
\cline { 2 - 7 } & Maintenance repair cost ratio $\left(\$ / \mathrm{ft}^{2}\right)$ & 3.396 & - & 6.9 & 0.8 & 1.3 \\
\hline \multirow{4}{*}{ LEED building } & Building value $(\$)$ & 78 & $461,975.0$ & $315,000,000.0$ & $44,344,000.0$ & $45,815,600.0$ \\
\cline { 2 - 7 } & Building area $\left(\mathrm{ft}^{2}\right)$ & 78 & 1036.0 & $565,000.0$ & $116,882.8$ & $103,683.0$ \\
\cline { 2 - 7 } & Maintenance repair cost $(\$)$ & 78 & - & $46,705,210.0$ & $4,120,486.0$ & $8,415,732.0$ \\
\cline { 2 - 7 } & Building value ratio $\left(\$ / \mathrm{ft}^{2}\right)$ & 78 & 176.2 & 937.3 & 399.0 & 131.9 \\
\cline { 2 - 7 } & Maintenance repair cost ratio $\left(\$ / \mathrm{ft}^{2}\right)$ & 78 & - & 10.2 & 0.7 & 1.9 \\
\hline
\end{tabular}

of university, building name, address, construction type, year of construction, stories, area, building values, and so on. The loss record includes subscriber, policy no., loss date, loss description, payment amount, etc. This data consists of 3.474 buildings belonging to 62 Canadian universities. Therefore, this study is limited to the university buildings belonging to the CURIE. The loss record is from 1988 to 2016 . The total number of records is 1.120 . The loss records are highly reliable because they are objectively evaluated and verified by qualified claim adjusters and engineers. This study collected each building's information, i.e., building values and maintenance and repair costs, from the organization.

The following buildings are used to generate contrast samples to maintain the homogeneity of the sample; the control sample consists of buildings which are built since 2006 and over $1.000 \mathrm{ft}^{2}$. The building value ratios and maintenance repair cost ratios of each group are estimated as the values of the buildings (\$) and the maintenance and repair costs (\$) divided by the building area $\left(\mathrm{ft}^{2}\right)$, as shown in Table 2 . The building value ratio and maintenance and repair cost ratio were transformed using natural logarithms.

\section{Analysis and results}

\subsection{Normality test}

This study uses a T-test to confirm the difference between the building value ratio and maintenance and repair cost ratio between the two groups, i.e., LEED and non-LEED buildings. The T-test should satisfy the assumption that the distribution of the data is normal.

Therefore, a normality test was performed for the collected data to analyze whether it has a normal distribution. As seen in Table 3, the Kolmogorov-Smirnov test was adopted to test the normality of the data. The P-values of 0.154 and 0.137 for the building value ratio and maintenance and repair costs ratio, respectively, are larger than 0.05 , thus describing data that is normally distributed.

Moreover, as seen in Figures 1, 2, and Table 3, the residual histograms (a) and the Q-Q plots (b) prove that the ratios are normally dispersed. A Q-Q plot is a scatter plot generated by substituting two sets of quantiles. The plot matches the observed quantiles of the data with the expected quantiles normally distributed. The observed quantiles are described as points and the expected quantiles are represented as a line. The point is on the line or close to the line, if the data is normally distributed. The Q-Q plots shows that the points are one the line or close

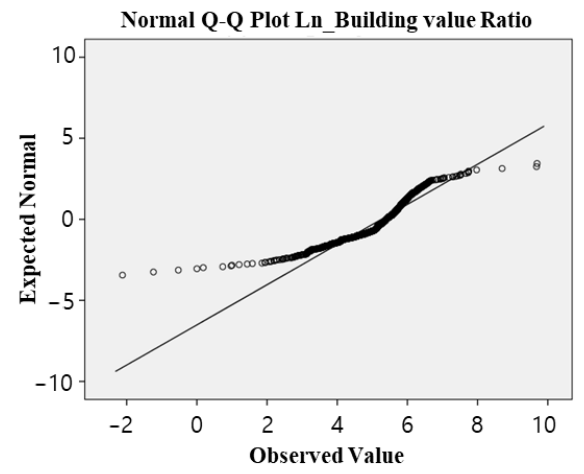

a)

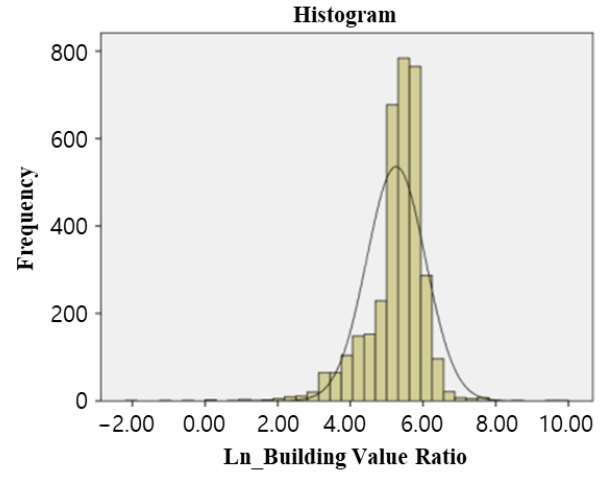

b)

Figure 1. Q-Q plot (a) and histogram (b) for building value ratio 


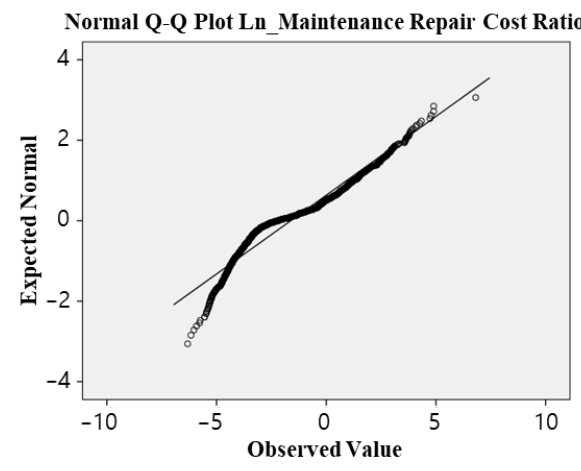

a)

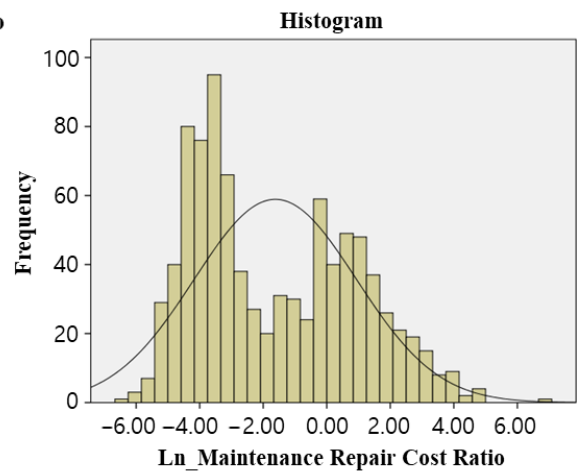

b)

Figure 2. Q-Q plot (a) and histogram (b) for maintenance and repair costs ratio

Table 3. Data normality test

\begin{tabular}{|l|c|c|}
\hline \multirow{2}{*}{} & \multicolumn{2}{|c|}{ Kolmogorov-Smirnov } \\
\cline { 2 - 3 } & Statistic & Sig. \\
\hline $\ln$ (Building value ratio) & 0.154 & 0.240 \\
\hline $\ln$ (Maintenance and repair cost ratio) & 0.137 & 0.200 \\
\hline
\end{tabular}

to the line which means that the ratios are normally dispersed. Residual histograms can also apply to determine if the variance is normally distributed. A proportioned bellshaped bar graph consistently distributed around it indicates that normal assumptions are true. The residual histograms are balanced bell shape that is not shifted to one side which prove that the ratios are normally dispersed. Consequently, those results demonstrate that the collected data is normally distributed.

\subsection{T-test}

A statistical approach is required to determine the degree of reliability describing the difference in building values between LEED certified buildings and non-LEED certified buildings. Therefore, this study affirms hypotheses 1 and 2 listed below that there is no difference between the ratio of LEED buildings and the ratio of non-LEED buildings.

Hypothesis 1 (Building value ratio)

$$
\begin{aligned}
& H_{0}: L B V R=N B V R ; \\
& H_{1}: L B V R \neq N B V R,
\end{aligned}
$$

where: $L B V R$ - building value per area for LEED certified buildings; $N B V R$ - building value per area for non-LEED certified buildings.
Hypothesis 2 (Maintenance and repair costs ratio)

$$
\begin{aligned}
& H_{0}: L M R R=N M R R ; \\
& H_{1}: L M R R \neq N M R R,
\end{aligned}
$$

where: $L M R R$ - maintenance repair cost per area for LEED certified buildings; NMRR - maintenance repair cost per area for non-LEED certified buildings.

Independent sample T-testing is a method used when comparing the mean values of a single population to reference values. If there is a difference between the two groups, that is a logical basis for a difference in building value, depending on whether LEED certification has been obtained.

Table 4 shows the results of the T-test. There is a significant difference in the building value ratio between LEED certified buildings (mean $=5.933, \mathrm{SD}=0.328$ ) and nonLEED buildings (mean $=5.242, \mathrm{SD}=0.808)$. The P-value of 0.000 is smaller than 0.05 , which confirms that the mean difference is statistically significant. This outcome reveals that LEED certification has an effect on building values. Specially, this study defines that the value of a LEED certified building is $49.9 \%$ higher than the value of a non-LEED certified building.

Finally, there is a significant difference in the maintenance repair cost ratio between a LEED certified building (mean $=-0.860, \mathrm{SD}=1.438)$ and a non-LEED building (mean $=-0.632, \mathrm{SD}=1.579$ ). The P-value of 0.000 is less than 0.05 , which implies the mean difference is statistically significant. This result affirms that LEED certification has an effect on maintenance and repair cost. Particularly, this study demonstrates that the maintenance and repair cost of a LEED certified building is $25.6 \%$ lower than the maintenance and repair costs of a non-LEED certified building.

Table 4. T-test results

\begin{tabular}{|l|l|c|c|c|c|}
\hline \multicolumn{2}{|c|}{ Category } & Mean & Std. Deviation & t-value & p-value \\
\hline Building value ratio & LEED & 5.933 & 0.328 & -7.340 & 0.000 \\
\hline \multirow{2}{*}{ Maintenance repair cost ratio } & Non-LEED & 5.242 & 0.808 & & \\
& LEED & -0.860 & 1.438 & -16.989 & 0.000 \\
\cline { 2 - 6 } & Non-LEED & -0.632 & 1.579 & & \\
\hline
\end{tabular}




\section{Discussion}

The construction cost of LEED certified buildings generally is more than non-LEED Certified buildings. The increase in construction costs is attributable to the cost of initial design of buildings, the use of relatively expensive eco-friendly materials, and the additional costs of supplying eco-friendly materials. However, due to cost savings and additional benefits of 50 to $65 \$\left(\mathrm{per} \mathrm{ft}^{2}\right)$ through energy and water conservation, reduction of maintenance costs, productivity improvement and health promotion, relatively high construction costs of environmentally friendly buildings will be offset in the long run. Even if LEED certified buildings cost a little extra in construction phases, the certified buildings have enough advantages to offset the additional costs. For example, due to cost savings and additional benefits of 50 to $65 \$\left(\right.$ per $\mathrm{ft}^{2}$ ) through energy and water conservation, reduction of maintenance costs, productivity improvement and health promotion, relatively high construction costs of environmentally friendly buildings will be offset in the long run. The economic benefits of this eco-friendly building are even greater in school building. The total fiscal benefits are about $\$ 70$ per $\mathrm{ft}^{2}$ includes health related cost, satisfaction of workers, performance of students and workers, improve student absenteeism, contributing to community development, and so on (Kats, 2006).

In addition, this study statistically strengthens the findings of previous studies. There are significant difference in the building value ratio and maintenance and repair cost ratio between the LEED certified buildings and non-LEED certified buildings. The mean differences are statistically significant, since the both P-value are less than 0.05. The building value ratio comparison result between the LEED certified building and non-LEED certified building proves that the LEED certified building value are statistically $49.9 \%$ greater than non-LEED certified building value. This result reinforces the past research that the green certification has positive influence to building value (Miller et al., 2008; Wiley et al., 2010; Eichholtz et al., 2010, 2013; Fuerst \& McAllister, 2009b). The maintenance and repair cost ratio comparison result between the LEED certified building and non-LEED certified building verify that the maintenance and repair cost ratio of LEED certified building are statistically $25.6 \%$ smaller than non-LEED certified building. This finding supports the former study that the green certification has the effect on reducing maintenance and repair cost (Kats, 2006; Kats, Alevantis, Berman, Mills, \& Perlman, 2003).

The green certified building has a positive economic effect (building price, maintenance cost) as shown in the past studies and CURIE statistical analysis results of this study. This economic impact cannot be summarized by one or two factors due to the nature of construction projects that are affected by innumerable outer factors. However, due to the general nature of green certified buildings, the quality and management of the process can be considered. Green certified buildings will be of higher quality in planning and design than non-green certified buildings because they are managed from the initial planning and design stage of the building. Furthermore, the high quality of these planning and design phases will also have a positive impact on the construction phase, leading to better construction quality. In addition, since most green certification buildings are invested heavily in comparison with non-green certification buildings, they can be better managed in design and construction management. This virtuous cycle of the qualitative factors of the green certification building will generate economic effect. Therefore, further research is needed to define and quantify the factors that will have an economic impact.

\section{Conclusions}

As public awareness of the efficiency and sustainability of buildings is increasing, the green building certification systems are rapidly spreading around the world. In accordance with this, research on the premium of the green building certification system is actively being carried out. However, since most of the research is limited to commercial and residential buildings, there is a lack of research on school facilities. To fill the gap, this study investigated the premiums for green-certified buildings used as educational facilities. In particular, this study used data from an insurance organization which insures universities in Canada to assess economic characteristics, including building value and maintenance and repair costs, for educational properties. The results show that a premium exists for LEED certified educational buildings. The value of a LEED certified building is $49.9 \%$ greater than the value of a non-LEED certified building. Moreover, the maintenance and repair costs of a LEED certified building is $25.6 \%$ less than the maintenance and repair costs of a non-LEED certified building. Therefore, it seems that the supplementary cost element increases the value of a green building beyond solely decreasing operating expenses. This result strengthens previous research that green building certification has an economically positive impact on school facilities. The results of this study can be used as an important reference for promoting the adoption of the green certification system. It can also be used as an important material explaining the economic effects of the green building certification system.

Nevertheless, further investigation is needed to improve understanding of the green building premium in other countries. There may be some differences when applying the certification system for green building in other countries, since the results of this study were conducted for buildings applying the LEED certification system in Canada. Consequently, it is necessary to conduct further studies on the benefit cost of certified buildings in other countries and further studies to verify the results of this study. In particular, in order to support the results of this study, it is necessary to identify factors that affect economic impacts through scientific analysis of different data sets in various countries, and also to quantify research on factors. 


\section{Acknowledgements}

This research was funded by Basic Science Research Program through the National Research Foundation of Korea (NRF) funded by the Ministry of Education (NRF2019R1F1A1058800).

\section{References}

Bon, R., \& Hutchinson, K. (2000). Sustainable construction: some economic challenges. Building Research \& Information, 28(5-6), 310-314. https://doi.org/10.1080/096132100418465

Building Research Establishment's Environmental Assessment Method. (1991). The Building Research Establishment (based in Watford, England, UK). Retrieved from https://www. breeam.com/

Chen, X., Yang, H., \& Lu, L. (2015). A comprehensive review on passive design approaches in green building rating tools. Renewable and Sustainable Energy Reviews, 50, 1425-1436. https://doi.org/10.1016/j.rser.2015.06.003

Eichholtz, P., Kok, N., \& Quigley, J. M. (2009). Why companies rent green: CSR and the role of real estate. Academy of Management Proceedings, 2009(1), 1-6. https://doi.org/10.5465/ambpp.2009.44248224

Eichholtz, P., Kok, N., \& Quigley, J. M. (2010). Doing well by doing good? Green office buildings. American Economic Review, 100(5), 2492-2509. Retrieved from https://www.aeaweb.org/ articles?id=10.1257/aer.100.5.2492

Eichholtz, P., Kok, N., \& Quigley, J. M. (2013). The economics of green building. Review of Economics and Statistics, 95(1), 50-63. https://doi.org/10.1162/REST_a_00291

Fuerst, F., \& McAllister, P. (2009a). An investigation of the effect of eco-labeling on office occupancy rates. The Journal of Sustainable Real Estate, 1(1), 49-64. https://doi.org/10.2139/ssrn.1431575

Fuerst, F., \& McAllister, P. (2009b). New evidence on the green building rent and price premium. https://doi.org/10.2139/ssrn.1372440

Gou, Z., \& Lau, S. S. Y. (2014). Contextualizing green building rating systems: case study of Hong Kong. Habitat International, 44, 282-289. https://doi.org/10.1016/j.habitatint.2014.07.008

Gou, Z., Lau, S. S. Y., \& Prasad, D. (2013). Market readiness and policy implications for green buildings: case study from Hong Kong. Journal of Green Building, 8(2), 162-173.

https://doi.org/10.3992/jgb.8.2.162
Ha, S. G., Son, K. Y., Kim, J. M., \& Kim, T. H. (2017). Comparison analysis of construction costs according to LEED and non-LEED certified educational buildings. Journal of the Korean Institute of Educational Facilities, 24(6), 3-10.

Heerwagen, J. (2000). Green buildings, organizational success and occupant productivity. Building Research \& Information, 28(5-6), 353-367. https://doi.org/10.1080/096132100418500

Kats, G. (2006). Greening America's schools costs and benefits. The U.S. Green Building Council. Retrieved from http://www.usgbc.org/Docs/Archive/General/Docs2908.pdf

Kats, G. H. (2003). Green building costs and financial benefits. Boston, Massachusetts Technology Collaborative. Retrieved from http://staging.community-wealth.org/sites/clone.community-wealth.org/files/downloads/paper-kats.pdf

Kats, G., Alevantis, L., Berman, A., Mills, E., \& Perlman, J. (2003). The costs and financial benefits of green buildings: $a$ report to California's sustainable building task force. California Department of Resources Recycling and Recovery.

Kim, J. M., Yang, W. Y., \& Min, J. K. (2012). A study on the variation of construction cost as graded LEED certification of office building. Journal of the Regional Association of Architectural Institute of Korea, 28(8), 161-168.

Leadership in Energy and Environmental Design. (1998). The U.S. Green Building Council (USGBC). Retrieved from https:// new.usgbc.org/leed

Lee, W. K. (2013). A study on additional construction cost for LEED certification on new construction. Seoul National University of Science and Technology.

May, P. J., \& Koski, C. (2007). State environmental policies: analyzing green building mandates. Review of Policy Research, 24(1), 49-65. https://doi.org/10.1111/j.1541-1338.2007.00267.x

Miller, N., Spivey, J., \& Florance, A. (2008). Does green pay off? Journal of Real Estate Portfolio Management, 14(4), 385-400. https://doi.org/10.5555/repm.14.4.m5g300025p233u24

Shendell, D. G., Prill, R., Fisk, W. J., Apte, M. G., Blake, D., \& Faulkner, D. (2004). Associations between classroom $\mathrm{CO}_{2}$ concentrations and student attendance in Washington and Idaho. Indoor Air, 14(5), 333-341. https://doi.org/10.1111/j.1600-0668.2004.00251.x

United States Environmental Protection Agency. (2000). Indoor air quality tools for schools (pp. 1-3). Retrieved from https:// www.epa.gov/iaq-schools/indoor-air-quality-tools-schoolsaction-kit

Wiley, J. A., Benefield, J. D., \& Johnson, K. H. (2010). Green design and the market for commercial office space. The Journal of Real Estate Finance and Economics, 41(2), 228-243. https://doi.org/10.1007/s11146-008-9142-2 